ARTICLE

\title{
Tax Administration Issues on Revenue Recognition after IFRS 15 Adoption in Indonesia
}

\author{
Prianto Budi Saptono and Ismail Khozen \\ Fiscal Administration, Faculty of Administrative Sciences, Universitas Indonesia, Depok, Indonesia \\ How to cite: Saptono, Prianto Budi \& Khozen, Ismail. (2021). Tax Administration Issues on Revenue \\ Recognition after IFRS 15 Adoption in Indonesia. Jurnal Borneo Administrator, 17 (2), 169-182. \\ https://doi.org/10.24258/jba.v17i2.877
}

\section{Article History}

Received: April 52021

Accepted: May 272021

\section{Keywords:}

IFRS adoption,

PSAK,

revenue recognition, income tax,

value-added tax.

\begin{abstract}
This study aims to provide a brief and analytical reporting on IFRS 15 adoption in Indonesia into PSAK 72 related to Income Tax and Value Added Tax (VAT) issues. The authors used a qualitative approach in conducting this study with data collection through in-depth interviews. Our findings demonstrate the need for entities to consider taxation issues that may arise due to revenue recognition developments. Unconformity that may arise between accounting and tax requires the entity to explain these differences by documenting them in advance. Taxpayers need to underline the burden of compliance arising from the IFRS 15 adoption, which is the compliance cost in the form of mark-to-market and realization taxation. In implementing PSAK 72 to align with the realization principle under Income Tax Law, the taxpayer compliance cost will increase by making detailed fiscal reconciliations. From the VAT perspective, the Taxable Entrepreneurs ("PKP") need to consider contract adjustments with the counterparty to ensure that the time of supply is the basis for determining the VAT payable. This research presents the gap between accounting and taxation so that it can also be a lesson to be applied in other countries.
\end{abstract}

\section{A. INTRODUCTION}

International Financial Reporting Standard (IFRS) adoption varies from country to country; some have made full adoption, while others have been gradual. Indonesia is one of those who adopted IFRS gradually (Laupe, 2018). In principle, IFRS convergence expects to produce different qualities arising from financial statements and earnings (Atqa et al., 2019). Before adopting IFRS, the accounting standards applicable in Indonesia were flexible standards that allowed different accounting methods to be applied for each company, giving rise to the possibility of creative accounting and earnings management (Andison, 2017). However, a study from Setiawan et al. (2019) shows that the IFRS adoption in Indonesia has decreased the earnings management behavior.

Concerning revenue recognition, IASB and FASB have agreed to issue IFRS that regulates revenue recognition from contracts with customers through IFRS 15. IASB states that the fundamental change in IFRS 15 is a general principle model of contract-based revenue recognition with the allocation of transaction prices as a reference in its measurement (IASB,

* Corresponding Author

Email : prianto.saptono@ui.ac.id 
2014). In addition, as a compilation of several standards, IFRS 15 introduces the concept of "performance obligation," which enables the entity to recognize revenue on the goods or services transfer to customers. Besides, IFRS 15 introduces a revenue recognition model when the entity has fulfilled its performance obligation. The consequence of fulfilling the performance obligation is the transfer of control over goods or services.

After the global introduction of IFRS 15, Statement of Financial Accounting Standard (SFAS or "PSAK") 72 was passed on July 26, 2017, and effectively came into force on January 1, 2020. PSAK 72 adopted IFRS 15 Revenue from Contracts with Customers. Therefore, the most appropriate way to understand PSAK 72 is by examining IFRS 15 as a reference in adopting PSAK 72 in Indonesia. IFRS 15 is a joint project between FASB and IASB. The IASB issues accounting standards in IAS and IFRS, while the FASB issues US GAAP. Compared to revenue recognition in the prior standard of IAS 8, IFRS 15 introduces guidance with more prescriptive requirements (Levanti, 2020). The new requirements could substantially change the policy regarding revenue recognition of implementing entities.

The issue that often arises when the convergence of IFRS with national accounting standards is the shadow of state intervention and other causes such as no modification when IFRS was adopted (Guerreiro et al., 2020). Countries that may not have implemented IFRS adoption and convergence are Bolivia and Guatemala (Carneiro et al., 2017). The accounting standards that apply in the two countries use instrumental logic related to taxation so that companies must follow standards based on the tax laws. When taxpayers have to run two systems in parallel (accounting and tax), it will be costly (Uzma, 2016). Several developing countries have modified their IFRS to suit domestic challenges such as economic, tax, and financial regulations in line with domestic conditions. These countries include China and India (Uzma, 2016).

For the context in Indonesia, the policymakers in 2020 changed the tax law twice through the omnibus law (Khozen et al., 2021). Since the new rules do not address accounting issues, questions arise about their concern for the field and the direction of Indonesian tax reform. Prior tax reform had taken place in three phases: the first reforms carried out in 1983, 1994, 1997; the second phase was in 2000; and the third phase was in 2004, 2005, 2007, 2009 (Rahman, 2017). According to Bawazier (2011), in post-1997, even though being costly and not well-planned and having political implications, the tax reform showed indications of failure.

Only the 1983 reform touched on technical rules by adopting accounting practices (Rahman, 2017). However, these rules are no longer relevant to current accounting developments (Budi \& Rahayu, 2021). Since only a few studies compare PSAK 72 adoption on taxation, resulting in some research scope. The approach in PSAK 72 related to revenue recognition based on predictions raises different concepts that underlie the recognition of income before and during the application of PSAK 72. Therefore, this paper is one of the first academic responses that aim to provide a brief report and analysis of the application of PSAK 72 in Indonesia to deal with administration issues regarding Income Tax and VAT.

\section{B. LITERATURE REVIEW}

The approach used to assess the connection between accounting and tax refers to the connection's stringency and the likelihood of maintaining that connection. Hoogendoorn (1996) developed a taxonomy of the connection between accounting and tax in 13 European Union countries. Hoogendoorn finds possibly identifying two types of connection that are essentially different and refer to the structures of "independence" and "dependence." The dependent connection shows a strong relationship between accounting and tax. Dependency is presumed to exist if financial statements refer to tax rules or taxable income is determined based on financial statements. On the other hand, an independent connection shows a weak 
relationship between accounting and tax. In other words, companies use different accounting policies to prepare financial reports and tax calculations.

After Hoogendoorn (1996), Lamb et al. (1998) developed a method of assessing the connection or conformity between (a) tax rules and practices and (b) financial reporting and practice. Lamb et al. (1998) focus on four countries (UK, US, France, and Germany). They categorize five cases of the connection between accounting and tax: Cases I, II, III, IV, and V. The assumption used for the five cases is that they occur in many countries. The main issue is the connection between accounting reporting practices and tax reporting at the operational level. Case I (disconnection) is a case where tax and accounting rules are different. Case II (identical connection) applies when the tax and accounting rules are the same. Case III (accounting leads) is for accounting standards affecting taxation and following accounting practices. Case IV (tax leads) is applicable when accounting does not have a sufficiently specific arrangement to follow tax rules. Case V (tax dominate) occurs when accounting rules are set aside since reliance follows tax rules for tax reporting purposes.

Gilbai (2014) models the level of the connection between accounting and tax after IFRS, as shown in Figure 1. The figure shows that Germany and the United States (US) occupy opposite accounting and tax relations positions. The US has a dualistic approach based on the significant separation between IFRSs and taxes. In this regard, the US has the flexibility to allow regulations to form the basis for preparing financial statements for tax purposes. In contrast, Germany is known for the very close connection between the tax system and GAAP. Referring to Figure 2, two countries in the European Union (Germany and the UK) are examples of countries with contrasting and different accounting traditions in Europe. Germany is an example of a country with a continental system, while England has an Anglo-Saxon system.

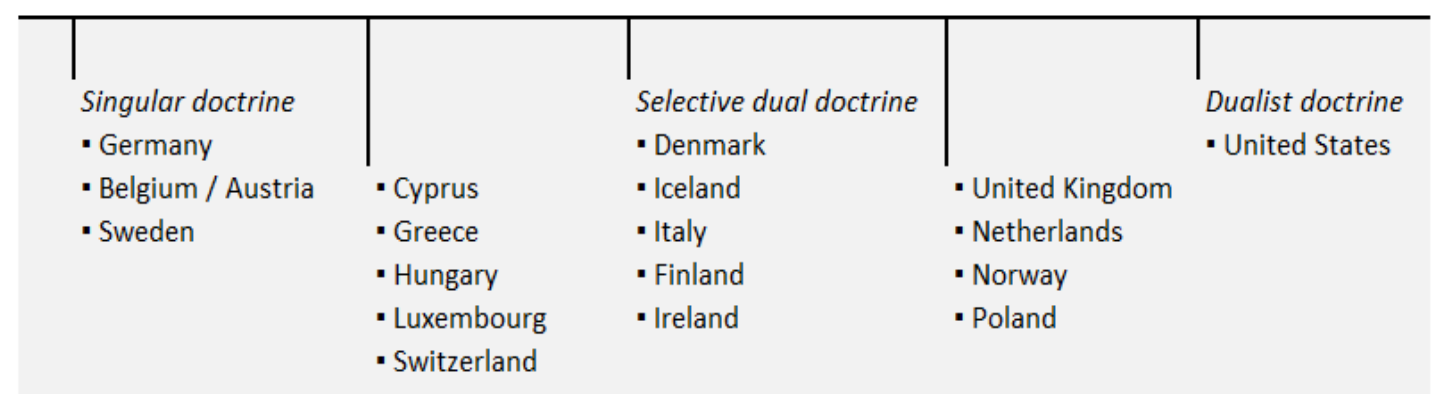

Source: adapted from Gilbai $(2014$, p. 8)

Figure 1. Model of Connection Level between Accounting and Tax in Europe

After the convergence of IFRS in Italy, Gavana et al. (2013) also researched the connection between accounting and tax using the approaches of Lamb et al. (1998) and Nobes and Schwencke (2006). The results show that companies that implement IFRS face a high level of disconnection when adjusting financial reports according to tax regulations. Besides, most taxpayers who apply local financial accounting standards in Italy are small and closed companies, so they do not need to communicate their financial reports to investors in the capital market. The financial statements of these companies are also rarely audited by public accountants. Therefore, when preparing financial reports, these companies still consider the tax aspect. Based on these conditions, Gavana et al. (2013) positioned the level of connection in Italy between the Anglo-Saxon accounting system and the Continental European system for the international context. 


\section{METHOD}

PSAK 72 that adopting IFRS 15 has been implemented in Indonesia effectively since early 2020. Some entities in Indonesia have also chosen to undertake early adoption of PSAK 72. The application of PSAK 72 as a standard with new principles opens opportunities for several studies. As a preliminary study on the impact of PSAK 72, this paper aims to provide a brief report and analyses the application of PSAK 72 concerning Income Tax and Value Added Tax issues that may arise. This study used a qualitative approach and analyses data sources from literature studies enriched with several case studies of the application and impact of PSAK 72. We also use data from in-depth interviews to provide an overview of the impact of the adoption of PSAK 72 on the fulfillment of Income Tax and Value Added Tax obligations for entities that apply PSAK 72. Research refers carried out Research-oriented open methods have carried out research-oriented open methods during the interview process, making it possible to explore informants' perspectives and feelings about a complex phenomenon (Brounéus, 2011).

This study conducted interviews purposively with some key resource persons. The first interviewee is an academics (Academician 1). The second is an official of Directorate General of Taxes (DGT official 1) becoming a member of the Financial Accounting Standards Board of the Institute of Indonesian Accountants (IAI) for the 2018-2020 period (PSAK standardsetter 1). The third is a policymaker of Corporate Income Tax Policy at DGT (Tax policymaker 1). The fourth is a tax consultant (Tax Consultant 1). The last interviewee is a tax practitioner who works for a go-public company having adopted PSAK 72 (Tax Practitioner 1). They are all chartered accountants.

Considering the quality of the data, the scope of the research, the nature of the topic, the amount of useful information obtained from each, the use of shadow data, and the qualitative methods and research design used (Morse, 2000), we agree with Dworkin (2012). Furthermore, he stipulated that based on the recommendation of many articles, book chapters, and books, the sample size in a qualitative study requires a minimum of five participants.

The data analysis in this research follows Creswell (2013) and consists of several activities. First, after collecting data and information from the field, we organized the data into several categories, transformed it into stories or descriptions, and wrote them into text. Second, regarding the amount of field study data we obtained, we manually re-presented it into several patterns and categories following codes and themes then interpreted it by triangulating it with accounting standards and tax laws. Fourth, we compared one interview result to others. Finally, we compared the interview results to documentation. We used such techniques to ensure that every conclusion in this study can be justified and has a high level of validity.

\section{RESULT AND DISCUSSION}

Starting in 2020, revenue recognition from contracts with customers in Indonesia refers to PSAK 72. Revenue recognition, according to PSAK 72, must use a lot of considerations and estimates. Therefore, it takes much detailed disclosure. Because of the large number of estimates, the entity should disclose all significant sources of estimating uncertainty and considerations to ensure the financial statements' users could understand the estimates and the judgments made in recognizing revenue from contracts (Van Wyk \& Coetsee, 2020). These judgments and estimates are to determine transaction prices and allocate them to each performance obligation so that the entity could recognize revenue. The current fully converged requirements for revenue recognition in IFRS 15 significantly improve revenue reporting quality and consistency while enhancing financial statements' comparability (Du et al., 2016).

As with IFRS 15, PSAK 72 issues are related to revenue recognition using a contractbased model, principles-based approach, and balance sheet orientation. The contract-based model focuses on the contracting parties' rights and obligations (Alibhai et al., 2019). In some cases, the IFRS 15 introduction has involved significant costs associated with developing 
additional computer software (Napier \& Stadler, 2020). However, the adoption of IFRS 15 makes it necessary for entities to assess the effects related to performance and contract use of accounting metrics as well as dividend payments, loan arrangements, compensation plans, taxation, domestic or transnational regulatory restrictions, and other institutional factors (Usurelu \& Dutescu, 2018).

PSAK 72 fully adopted IFRS 15, which became effective as of January 1, 2018. However, some arrangements were not adopted because they were deemed irrelevant, such as paragraph C10 regarding the SIC 31 Revenue-Barter Transactions Involving Advertising Services statement withdrawal. Also, Appendix D regarding consequential amendments to IFRS 1 Firsttime Adoption of International Financial Reporting Standards was not adopted because IAI has not adopted IFRS 1 in Indonesia. To better understand the application of PSAK 72 in Indonesia and its relationship with tax aspects, the following section briefly presents the recognition of income under PSAK 72 and administrative issues that arise regarding income tax and VAT.

\section{Revenue Recognition under PSAK 72}

Financial statement users judge a company's financial performance and prospects from revenue, showing it at the top of the income statement, indicating that revenue is an important metric (Boujelben \& Kobbi-Fakhfakh, 2020). However, one of the most fundamental problems standard-setters confront is revenue recognition (Kivioja, 2018). Following the principlesbased approach under IFRS (Guerreiro et al., 2014), PSAK 72 regulates the principles for recognizing and measuring all types of income with customers. Thus, PSAK 72 is the single standard for revenue recognition. Because the new standard is principles-based, entities have greater flexibility in exercising judgment in applying it (Bloom \& Kamm, 2014). There are five revenue recognition stages from contracts with customers, as summarized below.

\section{a) Identifying the Contract with Costumers}

If a contract has many components, the new framework in IFRS 15 could motivate companies to carefully consider whether they meet each element of performance requirements (Gee, 2016). Thus, the standards in IFRS 15 or PSAK 72 could be a handy tool to encourage entities to be more vigilant when reporting each contract component. This first step influences the next step, although there is no accounting personnel intervention (Ferreira, 2020). Compared with the prior processes implemented, IFRS 15 triggers entities to build more effective internal communications and improve internal control policies and procedures to establish effective internal control (Chen, 2019).

\section{b) Identifying the Performance Obligation}

Accounting treatment usually refers to only one performance obligation. However, many revenue arrangements have performance obligations more than just one. To determine the entity carries out multiple performance obligations or not, the entity uses stage two to evaluate and differentiate the products under the revenue arrangement (Boujelben \& Kobbi-Fakhfakh, 2020). Suppose the entity could separate the performance obligations from one another (fulfill the concept of being capable of being distinct). In that case, the entity must separately account for each performance obligation (Napier \& Stadler, 2020). If several performance obligations are interdependent and interrelated, the report is as a single unit.

\section{c) Determining the Transaction Price}

The transaction prices are often easy to determine because the customer usually agrees to pay a fixed amount to the entity over a short period. In other contracts, to determine the transaction price, an entity must consider several factors such as variable consideration, significant financing component, constraining estimates of variable consideration, the 
consideration payable to a customer, and non-cash consideration. The transaction price's determination should also reflect the effect of the time value of money if the contract contains a significant financing component (Napier \& Stadler, 2020; Trabelsi, 2018). Theoretically, the concept of the time value of money will ensure that the reporting entity accurately describes the transaction's economic value. However, according to Wärnlund and Klein (2020), some actors question the lack of an exact procedure in identifying whether a contract contains a significant financing component. The absence of clear criteria can lead to unfaithful representation.

\section{d) Allocating the Transaction Price to Performance Obligations}

In the fourth stage, the entity allocates the transaction price to each contractual performance obligation. The allocation uses the "relative stand-alone selling prices" of the promised goods or services. It is at the contract's inception but without adjustment to reflect subsequent changes in the goods or services' stand-alone selling price. The best evidence for determining a stand-alone selling price is the price of a good or service that is observable when the entity sells the goods or services separately (BC276). An entity should estimate the selling price of goods or services that do not have an observable stand-alone selling price and maximize the use of observable inputs when making such estimates.

\section{e) Recognizing Revenue}

The implication of applying IFRS 15 is that the entity recognizes revenue from customers based on the completion of the contract terms and conditions, in the sense that the agreed contractual obligations have been rendered (Alotibi, 2018). Determining the contract completion stage can use several ways, including the proportion of contract costs incurred for work with performance to date with the estimated total contract costs, a survey of work performed, or completion of the physical proportion of the contract work (Akinmoladun, 2019). The entity's revenue recognition is when (or as) it fulfills its performance obligations (EY, 2018) by transferring the promised goods or services (i.e., assets) to the customer. Assets are transferred when (or during) the customer obtains control of the asset.

\section{Issues concerning Income Tax}

The tax implications of the enactment of PSAK 72 can be analyzed through tax accounting development since 1983 under the Income Tax Law (Law Number 7/1983) era. Explicitly, the explanation of Article 13 paragraph (1) of the Income Tax Law includes the reference to the bookkeeping of 1984 Indonesian Accounting Principles (PAI) (IAI, 1984). The 1984 PAI reference for tax accounting lasted until 2000, following the explanation of Article 28 paragraph (4) of the General Provisions and Tax Procedures Law (Law No. 9/1994). Furthermore, from 2001 to 2011, following the law (Law No. 16/2000; Law No. 28/2007), tax accounting for public companies refers to the PSAK developed based on the Conceptual Framework for the Preparation and Presentation of Financial Statements (KDPPLK) (IAI, 1994). Since 2012, tax accounting continues referring to PSAK, but the development of PSAK refers to KDPPLK (IAI, 1994) and Conceptual Framework for Financial Reporting (KKPK) (IAI, 2016).

Upon the IFRS 15 adoption, many entities will change the total contractual considerations measurement and its split among the several elements deliverable in a single contract (Berchowitz \& Whitehead, 2014). The IFRS 15 introduction's possible effects could differ in each industry (Tutino et al., 2019). Therefore, entities applying PSAK 72 must begin to analyze the impact of IFRS 15 or PSAK 72 on their business, including taxation (Oncioiu \& Tănase, 2016). The root problem that could cause tax disputes related to revenue under PSAK 72 is the basis for measuring income according to PSAK 72, which uses many considerations and 
estimates. The main focus of PSAK 72 is a balance sheet orientation so that the revenue recognition basis is a fair value (FVA) approach. Meanwhile, tax recognition is still motivated by the accounting regulations in 1984 with an income statement orientation and HCA.

According to Budi and Rahayu (2021), the income tax concept in Indonesia relates to accrual accounting, received or accrued. Accrual accounting under Income Tax Law refers to the accrual concept in 1983, which still adheres to historical accounting. Meanwhile, the current accrual accounting concept has adopted fair value accounting. Concepts in taxation that have not adapted to the latest developments may cause problems. Therefore, the choice of future tax policy will always refer to one of the three available options (Saptono \& Khozen, 2021a): (a) realization of taxation, (b) accrual taxation, or (c) hybrid taxation. Each of the taxation options could increase compliance costs. Such a statement refers to one of the academics from the University of Indonesia, quoted as follows:

"From both sides, the compliance cost is high. The problem of a dispute between the tax authorities and the company or taxpayer is also heavy. It is better, strengthening human resources in the field of taxation first to understand these standards." (Academician 1)

For the realization of taxation, compliance costs are a fiscal reconciliation process that must be more detailed. According to accounting and tax, the income value may differ continuously, even though the proofing process for this type will be more straightforward. For mark-to-market taxation, the compliance cost is in the form of a burden of proof for the taxpayer. The burden of proof relates to estimates and professional judgment for measuring income under accounting and tax. As we are familiar with the adoption of IFRS 15 still requires professional interpretation and judgment, which may cause the accounting treatment to be erroneous or divergent (Haggenmüller, 2019).

Prior studies also show that one of the significant drawbacks of IFRS is that increased demand for interpretation and more excellent judgment skills can reduce the reliability and credibility of financial reporting (Wärnlund \& Klein, 2020). Moreover, they exemplify, countries tend to succumb to bias and interpret IFRS based on national interests. Therefore, Guerreiro et al. (2014) state the importance of investigating the new ways of accounting practices that developed due to IFRS adoption, which will provide a better understanding of how to institutionalize changes in national and international settings. For the context of PSAK 72 implementation in Indonesia, our discussion boils down to the fact that there is an intense desire of business actors so that the next taxation provisions rely on IFRS, as disclosed below.

"The easiest way, in my opinion, is the standard in taxation to follow IFRS. If taxes do not follow IFRS in this case, there will be many changes that require fiscal correction, which will make it even more complicated. Therefore, the tax standard is just the same as IFRS. After all, it has its criteria. Just stay consistent." (Tax consultant 1)

The concept of income refers to an accrual accounting concept under Article 4 paragraph (1) Income Tax Law. In contrast, tax accounting refers to the explanation memory of Article 28 paragraph (7) General Provision and Procedure Law. If we use historical interpretation, the accrual accounting model in the Income Tax Law refers to the realization. When textual interpretation is applied, the accrual accounting concept in the Income Tax Law refers to accrual taxation or mark-to-market taxation because tax provisions refer to accounting standards (Budi \& Rahayu, 2021). Taxation based on realization taxation is in line with the ability to pay principal and the concept of wherewithal to pay (Saptono \& Khozen, 2021b). However, the principles adopted by taxation are contradictory to the principle-based approach adopted by IFRS 15 and later PSAK 72. These differences can disrupt the company's cash flow 
since taxes owed may mature faster from a business perspective. Tax practitioners in one of the public companies that have carried out the early implementation of IFRS complained about this.

"Since 2019, we have carried out an early adoption of PSAK 72. After that, there has been a new assessment of the performance obligation. The income recognition is slightly different from the previous one. Anyhow, when it comes to performance obligations, revenue recognition will be slightly smaller. However, the recognition of income from a tax perspective becomes fixed so that it is more significant than commercial since taxation did not adopt IFRS. "(Tax Practitioner 1)

The tax reporting orientation did not shift from the income statement to the balance sheet, and the regulatory model still uses a rules-based approach. According to a rules-based approach, the most appropriate tax imposition option for revenue from contracts with customers is realization taxation. The choice of realization taxation is consistent with the realization taxation on unrealized gains/losses from financial instruments under PSAK 71 (adopting IFRS 9 Financial Instruments). As additional information, the determination of transaction prices in PSAK 72 also considers the significant funding component measured based on PSAK 71. Therefore, with the classical paradigm still valid in the income tax law, the entities or taxpayers need to adjust their contracts to consider realization principles. In other words, taxpayers need to continue making fiscal reconciliations even more significantly, as confirmed by an informant (PSAK standard-setter 1 ).

\section{Issues concerning Value Added Tax}

The question from a VAT perspective is, "When the entity that adopts PSAK 72 should recognize revenue?" In this regard, it is either at a point in time or over time. The VAT issue arises regarding the place of supply, the tax invoice's issuance (time of supply), and the tax base amount. For VAT base, it is often clear that the tax base for goods is the selling price while for services is the replacement. However, new problems may arise when the entity promises additional performance obligations in the contract. The place of supply is vital because the VAT Law applies in an area where the tax burden is generally on consumers' shift according to Indonesia's destination principle. Of the five stages of revenue recognition in PSAK 72, revenue recognition is when the transfer of control occurs. The transfer of control occurs between the entity and the customer, the seller and the buyer. The transfer of control occurrence over goods is at a point in time while services tend to be over time.

Control includes the ability to prevent another entity from directing the asset's use and obtaining benefits from it (Van Wyk \& Coetsee, 2020). When the entity has delivered the goods, the buyer also receives control over the goods. The timing issue arising from the delivery will determine the taxation aspects. Time of control as the basis for revenue recognition often becomes a dispute because the provisions in Article 13 paragraph (1a) of the VAT Law use the term delivery, which has multiple interpretations. Although there are already more technical arrangements through Article 17 of Government Regulation Number 1/2012 and its amendments, the details of "time of delivery" according to the provisions mentioned above still lead to disputes due to different perspectives between the taxpayer/tax consultant and tax office authority. In the case of delivery of goods, it may be simpler than services. We recognize two approaches: FOB shipping point and FOB destination concerning the delivery of goods. When the goods leave the warehouse (shipping point), there is a transfer of title at that time; or the determination for "at a point in time" is when the goods arrive at the buyer's warehouse (FOB destination).

However, determining the time of control for services' performance obligations is not as easy as the goods delivery. Transfer of control for over time criteria of the services may fall 
into one of the following three criteria. First, when the customer receives and consumes the entity's benefits simultaneously as long as the entity carries out its performance obligation, for example, in routine or recurring services (such as cleaning services) and cargo transportation services (Deloitte, 2016). Second, when the entity's performance obligation creates or increases assets controlled by customers - for example, construction services based on the percentage of completion method (PoCM). Third, when the entity's performance obligation does not create an asset with alternative uses for the entity, the entity has the right to enforceable payments for the performance completed to date. An entity performs over time revenue recognition for services if fulfilling one of the three criteria above. If does not meet the criteria, the entity shall recognize revenue at a point in time.

In the Indonesian context, VAT is payable when it occurs earlier between the date of supply of the taxable goods/services or the date of receipt of prepayments $(E Y, 2015)$. The concept of time of supply or "basic tax point" specifies when goods are purchased or sold for VAT purposes. Besides, the primary tax point determines when the service is delivered or received for VAT purposes. The date is essential because it will determine the time to create a Tax Invoice and the VAT reporting period to account for the output tax and input tax. From the policy side, the taxation provisions in Indonesia that have regulated the time of supply are: Article 13 paragraph (1) and (1a) Law no. 42/2009; Article 17 Government Regulation No. 1/2012; Minister of Finance Regulation No. 151/PMK.03/2013; and the Director-General of Taxes Circular Letter Number SE-50/PJ/2011.

Even though the time of supply regulations are pretty straightforward, there are still frequent tax disputes in practice due to different interpretations of the time supply. Previous experiences show that tax disputes have increased concerning differences in tax authority and taxpayers' interpretation (Saptono \& Khozen, 2021c). When dissenting interpretations occur, the contract takes a vital role to ensure the tax obligation between the entity and the customer. For this reason, Walker and Place (2020) analogize contracts as "kings" in their purpose of determining the amount of VAT payable. The identification of rights and obligations, including the timing of their performance, boils down to the contract. Therefore, it is in the taxpayers' interest to ensure that their contracts protect them from the adverse financial implications that may arise due to VAT (PwC, 2018). However, the problem will become more acute if the delivery timing in the contract between the entity and the customer is obscure (OECD, 2017).

Responding to the differences that may arise between accounting and tax, one of our research informants (Tax Policymaker 1) emphasized that the highlighted element to provide legal certainty is a more profound insight into legal contracts. Each contract needs to include arrangements regarding four basic concepts to minimize the risk of VAT payable and avoid ambiguity: consideration paid (e.g., cash or in-kind payments); nature of supply (e.g., goods, services, tangible property, real property, intellectual property); time of supply (e.g., when the VAT is payable); and place of supply (e.g., domestic or foreign transactions) (KPMG, 2017). With a more explicit contractual arrangement, the entity does not have to make excessive adjustments to equalize income tax, VAT, or estimates and judgments under PSAK 72. The contractual approach can result in greater certainty and consistency in determining responsibility for collecting and calculating VAT, emphasizing that contractual arrangements should minimize ambiguity and contradictions (OECD, 2017).

\section{E. CONCLUSION}

After PSAK 72 becomes effective, starting in 2020, the implementing entity must use many judgments and estimates in recognizing revenue. Considerations and estimates made by the entity should also consider taxation issues that arise from the development of revenue recognition approaches. We identify several issues that arise under PSAK 72 concerning taxation. First, promises to customers can raise questions from tax authorities regarding the 
record in the financial statements. The emergence of promises requires entities to carry out fiscal reconciliation. Second, PSAK 72 requires consideration in identifying transaction prices, such as but not limited to a significant financing component, which seems to generate interest expenses. The appearance of interest expense in the financial statements will raise questions regarding the tax aspects, thus requiring the entity to carry out fiscal reconciliation. Third, establishing an expected value for a particular transaction causes the entity to recognize unrealized gain. Because the Income Tax Law still embraces realization taxation, disputes may also occur so that the entity needs to explain why the expected value does not have a tax obligation. Fourth, when an entity identifies each performance obligation and the transaction price allocation, the entity needs to consider the taxation aspects that arise from each transaction.

For taxpayers, the implementation of PSAK 72 creates compliance burdens in the form of mark-to-market (accrual) taxation and realization taxation. The transformation carried out by PSAK 72 adds to the burden of compliance in the form of a burden of proof because taxpayers need to make estimates and professional judgments in measuring income according to accounting and tax. In adjusting the realization principle under Income Tax Law, there will be increased taxpayer compliance costs. The costs are related to a detailed fiscal reconciliation process related to income determination according to accounting and tax, which tend to be different. While the VAT perspective concerning the application of PSAK 72 is related to the time of supply, the time of supply becomes the basis for determining when the VAT payable is a benchmark in the issuance of tax invoices and the reporting period for periodic VAT returns. To adapt to PSAK 72, Taxable Entrepreneurs ("PKP") need to make or revise cooperation contracts with counterparties. A written cooperation contract needs to explicitly regulate the clause regarding the time of supply to accommodate VAT issues.

The scientific contribution of this research is in the area of public policy, particularly tax policy, expected to take into account the presented findings. Policymakers can identify measures that tax authorities can pursue by addressing the growing disparity between accounting and tax treatment due to the convergence of IFRS. These efforts are related to tax policies that the tax authorities can select after IFRS adoption in Indonesia, as described in this study. The gap between accounting and tax that we present in this study also can be a lesson for policy consideration in other countries. However, one of the limitations encountered in this study is that among four accounting pillars that currently apply in Indonesia, this study is only concerned with PSAK. Moreover, of the existing accounting arrangements, this study's income tax and VAT aspects only focus on the standards under PSAK 72. Future research can complement these limitations by examining tax administration issues based on other standards, not only IFRS 15, and conducting further investigations from empirical data.

\section{Acknowledgment}

This paper is part of the principal author's honorary dissertation. The principal author would like to thank Prof. Dr. Gunadi, M.Sc., Akt, and Dr. Ning Rahayu, M. Si., from the University of Indonesia, for their invaluable guidance throughout the research process.

\section{Contributorship}

In writing the manuscript, both authors have an equivalent contribution. However, the first author contributes further to data collection.

\section{REFERENCES}

Akinmoladun, F. (2019). IFRS 15 and Its Legal Implications for Nigerian Construction Companies. Construction Law International, 14 Construction L. Int'l 35, 38. 
Alibhai, S., Bakker, E., Balasubramanian, T. V., Bharadva, K., Chaudhry, A., Coetsee, D., .. . van der Merwe, M. (2019). Revenue from Contracts with Customers. In Wiley Interpretation and Application of IFRS Standards (pp. 481-520).

Alotibi, N. (2018). International Financial Reporting Standard (IFRS) 15 Revenue from Contracts with Customer. Journal of Internet Banking and Commerce, 23(3), 1-9.

Andison. (2017). Hubungan adopsi IFRS PSAK No.16 (revisi 2007) dengan discretionary accruals sebagai alat manajemen laba serta pengaruhnya terhadap nilai perusahaan. AKRUAL: Jurnal Akuntansi, Vol 8, No 2, (April) 2017.

Atqa, A. A., Lee, K.-H., \& Mohd-Saleh, N. (2019). Has IFRSs Improves Predictions of Future Cash Flows? Evidence from Malaysia. International Journal of Business and Society, Vol. 20 No 2, 2019, 851-869.

Bawazier, F. (2011). Tax reform in Indonesia Indonesian Journal of Legislation, Vol 8(No 1).

Berchowitz, G., \& Whitehead, S. (2014). IFRS 15: Revenue recognition will never be the same again. Accountancy SA, 27-29.

Bloom, R., \& Kamm, J. (2014). Revenue recognition: How we got here and where it will take us. Financial Executive, 30(3), 48-52.

Boujelben, S., \& Kobbi-Fakhfakh, S. (2020). Compliance with IFRS 15 mandatory disclosures: an exploratory study in telecom and construction sectors. Journal of Financial Reporting and Accounting, Vol. 18 No. 4, 2020 pp. 707-728. doi:10.1108/JFRA-102019-0137

Brounéus, K. (2011). In-depth Interviewing: The process, skill and ethics of interviews in peace research. In K. Höglund \& M. Öberg (Eds.), Understanding Peace Research: Methods and Challenges. New York: Routledge.

Budi, P., \& Rahayu, N. (2021). Could the next Indonesian income tax law adopt to the concept of income under IFRS? International Journal of Economic Policy in Emerging Economies, 2021 Vol.14 No.2, pp.151 - 173.

Carneiro, J., Rodrigues, L. L., \& Craig, R. (2017). Assessing international accounting harmonization in Latin America. Accounting Forum, 41(3), 172-184. doi:10.1016/j.accfor.2017.06.001

Chen, D. (2019). Analysis on New Revenue Standard's Impacts on Revenue Disclosure. Paper presented at the 2019 3rd International Conference on Education, Management and Social Science (EMSS 2019).

Creswell, J. W. (2013). Qualitative Inquiry and Research Design (3 ed.). Washington DC: SAGE Publications, Inc.

Deloitte. (2016). A Roadmap to Applying the New Revenue Recognition Standard. Retrieved from https://www2.deloitte.com/content/dam/Deloitte/au/Documents/audit/deloitteau-audit-roadmap-applying-new-revenue-recognition-2016-191216.pdf

Du, N., Alford, R. M., \& Smith, P. L. (2016). Do GAAP And IFRS Differ In Collectiblity Judgments Related To Revenue Recognition? Journal of Applied Business Research, 32(6), 1675-1686. doi:http://dx.doi.org/10.19030/jabr.v32i6.9815

Dworkin, S. L. (2012). Sample Size Policy for Qualitative Studies Using In-Depth Interviews. Archives of Sexual Behavior, 41(6), 1319-1320. doi:10.1007/s10508-012-0016-6

EY. (2015). Worldwide VAT, GST and Sales Tax Guide: EYGM Limited.

EY. (2018). IFRS 15 Revenue from Contracts with Customers: A closer look at IFRS 15, the revenue recognition standard. (Updated October 2018). Retrieved from https://assets.ey.com/content/dam/ey-sites/ey-com/de_de/topics/ifrs/ey-applyrevenue-updated-oct-2018.pdf

Ferreira, A. F. M. M. (2020). The Impact of IFRS 15 on the Telecommunications Sector - the Case of Portuguese and Spanish Listed Companies. Faculdade de Economia, Universidade do Porto, 
Gavana, G., Guggiola, G., \& Marenzi, A. (2013). Evolving Connections Between Tax and Financial Reporting in Italy. Accounting in Europe, 10(1), 43-70. doi:10.1080/17449480.2013.774733

Gee, T. (2016). Will IFRS 15 bring clarity or confusion? Bottom Line, 32(5), 14.

Gilbai, E. (2014). Taxation Versus IFRS: Investment Property as a Test Case (Part 1). The Practical Tax Lawyer, 29(1), 5-21.

Guerreiro, M., Rodrigues, L. L., \& Craig, R. (2020). Institutional Theory and IFRS: An agenda for future research. Spanish Journal of Finance and Accounting/Revista Espanola de Financiacion y Contabilidad. doi:10.1080/02102412.2020.1712877

Guerreiro, M. S., Rodrigues, L. L., \& Craig, R. (2014). Changing from a Rules-based to a Principles-based Accounting Logic: A Review. Australasian Accounting, Business and Finance Journal, 8(2), 2014, 110-120. doi:10.14453/aabfj.v8i2.8

Haggenmüller, S. (2019). Revenue Recognition under IFRS 15: A Critical Evaluation of Predefined Purposes and Implications for Improvement. University of Gloucestershire,

Hoogendoorn, M. N. (1996). Accounting and taxation in Europe - A comparative overview. European Accounting Review, 5(sup1), 783-794. doi:10.1080/09638189600000050

IAI. (1984). Prinsip Akuntansi Indonesia 1984. Jakarta: IAI.

IAI. (1994). PSAK No. 30 Akuntansi Sewa Guna Usaha: In IAI, Standar Akuntansi.

IAI. (2016). Kerangka Konseptual Pelaporan Keuangan. In IAI, SAK - Standar Akuntansi Keuangan: Efektif per 1 Januari 2017. Jakarta: IAI.

IASB. (2014). IFRS 15 Revenue from Contracts with Customers. London: IFRS Foundation.

Khozen, I., Saptono, P. B., \& Ningsih, M. S. (2021). Questioning Open Government Principle within the Law-Making Process of Omnibus Law in Indonesia. SOSHUM: Jurnal Sosial dan Humaniora [Journal of Social Sciences and Humanities], Volume 11(2).

Kivioja, T. (2018). The Impact of IFRS 15 on Analysts' Forecast Accuracy. Oulu Business School, University of Oulu,

KPMG. (2017). Contracts and VAT. Retrieved from https://assets.kpmg/content/dam/kpmg/bs/pdf/2017-08-VAT-and-contracts-v2.pdf

Lamb, M., Nobes, C., \& Roberts, A. (1998). International Variations in the Connections Between Tax and Financial Reporting. Accounting and Business Research, 28(3), 173188. doi:10.1080/00014788.1998.9728908

Laupe, S. (2018). Role of Culture and Law Enforcement in Determining the Level of IFRS Adoption. European Research Studies Journal, Volume XXI, Issue 1, 2018, pp. 52 - 64.

Levanti, D. (2020). Applicability of IFRS 15 principles for the banking industry: an analysis with reference to the credit institutions in Romania. Ecoforum Journal, 9(2).

Morse, J. M. (2000). Determining sample size. Qualitative Health Research, 10, 3-5.

Napier, C. J., \& Stadler, C. (2020). The real effects of a new accounting standard: the case of IFRS 15 Revenue from Contracts with Customers. Accounting and Business Research, 50(5), 474-503. doi:10.1080/00014788.2020.1770933

Nobes, C., \& Schwencke, H. R. (2006). Modelling the links between tax and financial reporting: A longitudinal examination of norway over 30 years up to IFRS adoption. European Accounting Review, 15(1), 63-87. doi:10.1080/09638180500510418

OECD. (2017). Mechanisms for the Effective Collection of VAT/GST When the Supplier Is Not Located In the Jurisdiction of Taxation. Retrieved from https://www.oecd.org/tax/taxpolicy/mechanisms-for-the-effective-collection-of-VAT-GST.pdf

Oncioiu, I., \& Tănase, A.-E. (2016). Revenue from Contracts with Customers under IFRS 15: New Perspectives on Practice. EuroEconomica, Vol 35, No 2.

PwC. (2018). Legal aspects of VAT implementation. Retrieved from https://www.pwc.com/m1/en/tax/vat-in-the-middle-east/pdf/implementationflyers/how-vat-impacts-you-legal-aspects-of-vat.pdf 
Rahman, A. (2017). A lesson from implementation of tax reforms in Indonesia and Vietnam. $\begin{array}{llll}\text { Jurnal Borneo } & \text { Administrator, }\end{array}$ doi:https://doi.org/https://doi.org/10.24258/jba.v13i1.276

Saptono, P. B., \& Khozen, I. (2021a). Income Tax and VAT Issues Concerning Leases after IFRS 16 Convergence in Indonesia. The Indonesian Journal of Accounting Research (IJAR), Vol 24, (No 2), 259-288.

Saptono, P. B., \& Khozen, I. (2021b). Other Comprehensive Income and Its Tax Implications in Indonesia. International journal of scientific and research publications, Volume 11(Issue 1).

Saptono, P. B., \& Khozen, I. (2021c). VAT Issues on Omnibus Law in Indonesia and Their Administrative Implications. International Journal of Scientific and Research Publication, Volume 11, Issue 2, pp 130-139.

Setiawan, D., Taib, F. M., Phua, L.-K., \& Chee, H.-K. (2019). IFRS and Earnings Management in Indonesia: The Effect of Independent Commissioners. International Journal of Business and Society, Vol. 20 No.1, 2019, 37-58.

Trabelsi, N. S. (2018). IFRS 15 Early Adoption and Accounting Information: Case of Real Estate Companies in Dubai. Academy of Accounting and Financial Studies Journal, 22(1), 1-12.

Tutino, M., Regoliosi, C., Mattei, G., Paoloni, N., \& Pompili, M. (2019). Does the IFRS 15 impact earnings management? Initial evidence from Italian listed companies. African Journal of Business Management, 13(7), 226-238. doi:https://doi.org/10.5897/AJBM2018.8735

Usurelu, V. I., \& Dutescu, A. (2018). IFRS 15 - the seventh wave of Norwalk Agreement's convergence Roadmap. Paper presented at the Proceedings of the 12th International Conference on Business Excellence.

Uzma, S. H. (2016). Cost-benefit analysis of IFRS adoption: developed and emerging countries. Journal of Financial Reporting and Accounting, 14(2), 198-229. doi:10.1108/JFRA-01-2015-0019

Van Wyk, M., \& Coetsee, D. (2020). The adequacy of IFRS 15 for revenue recognition in the construction industry. Journal of Economic and Financial Sciences, 13(1), 13 pages. doi:https://doi.org/10.4102/jef.v13i1.474

Walker, E., \& Place, D. (2020). VAT on damages and contract terminations. Tax Journal, July 2020. Retrieved from https://www.taxjournal.com/articles/vat-on-damages-andcontract-terminations

Wärnlund, A., \& Klein, T. (2020). IFRS 15: A critical evaluation of the newly issued revenue recognitions standard's ability to reflect economic reality. School of Economics and Management, Lund University, 
